\title{
Evidence for coabundance of leafminer flies and whiteflies in melon crops
}

\author{
Leandro José Uchôa Lemos (D), Tiago Cardoso da Costa-Lima2,* (D), Wesley Augusto Conde Godoy (D), \\ Roberto Victor Barros ${ }^{4}$ (D), Reginaldo Barros 5 (D) \\ 1. Instituto Federal do Sertão Pernambucano - Campus Petrolina Zona Rural - Petrolina (PE), Brazil. \\ 2. Empresa Brasileira de Pesquisa Agropecuária - Laboratório de Entomologia da Embrapa Semiárido - Petrolina (PE), Brazil. \\ 3. Universidade de São Paulo - Escola Superior de Agricultura “Luiz de Queiroz" - Departamento de Entomologia e Acarologia - Piracicaba (SP), \\ Brazil. \\ 4. Universidade Federal da Paraíba - Departamento Fitotecnia e Ciências Ambientais - Campina Grande (PB), Brazil \\ 5. Universidade Federal Rural de Pernambuco - Departamento de Agronomia - Laboratório de Biologia de Insetos - Recife (PE), Brazil.
}

Received: Nov. 14, 2019 | Accepted: Oct. 6, 2020

Section Editor: Luís Garrigós Leite

*Corresponding author: tiago.lima@embrapa.br

How to cite: Lemos, L. J. U., Costa-Lima, T. C., Godoy, W. A. C., Barros, R. V. and Barros, R. (2021) Evidence for coabundance of leafminer flies and whiteflies in melon crops. Bragantia, 80, e0421. https://doi.org/10.1590/1678-4499.20190459

\begin{abstract}
Interspecific competitions are important mechanisms in structuring ecological communities, including agroecosystems, in which different species may share the same food resource. In melons, two major pests coexist in time and space, Liriomyza sativae Blanchard (Diptera: Agromyzidae) and Bemisia tabaci (Gennadius) (Hemiptera: Aleyrodidae). The former feeds on the leaf mesophyll, while the latter on the phloem sap. Therefore, the same niche exploitation can trigger interactive processes between both populations. The present research aimed to determine if there are positive or negative interactions between whiteflies and leafminers under field conditions. The experiment was conducted in four commercial melon fields in northeast Brazil in two planting seasons. Thirty random plants were weekly selected for detection of whitefly nymphs and leafminer larvae throughout the entire crop cycle. The data was organized and analyzed considering the species abundance of L. sativae (larvae) and B. tabaci (nymphs and adults) in the same plant. Thus, the coabundance of species was investigated by using regressions with Poisson errors. The results suggest different fractions of negative, positive and neutral (not significant relationships) coabundance between the two species. Among 34 significant interactions, 56\% were negative, suggesting that more than half of significant interactions are due to interspecific competition with negative coabundance.
\end{abstract}

Key words: Liriomyza sativae Blanchard, Bemisia tabaci (Gennadius), Cucumis melo L. semi-arid.

\section{INTRODUCTION}

Interspecific interactions between populations of organisms describe relationships capable of regulating patterns of distribution, abundance and species diversity within ecological communities (Kaplan et al. 2011). Particularly, competition could be defined as a reduction in the survival rate of a particular species, affecting its population growth through interference from another or even by resource competition, in which an organism is displaced by a more aggressive one (Begon et al. 2005). Strategies are also used by species to coexist and avoid competition, such as niche segregation and spatial or temporal resource partitioning (Chesson 2000; Di Bitetti et al. 2009).

Co-occurrence patterns have been a central concern in community ecology, particularly to investigate segregation and/or grouping in animal communities (Gotelli 2000). However, this approach is characterized particularly by analysis of 
presence-absence matrices with "null model" randomization tests (Gotelli 2000), structure that does not allow considering the abundance of species, an important aspect to evaluate interactive processes in local scale (Brodie et al. 2018).

Bemisia tabaci (Gennadius) and Liriomyza sativae Blanchard are the main pests of melon in northeast Brazil (Chagas et al. 2019). The whitefly nymphs and adults feed by inserting their mouthpieces in the leaf and sucking the phloem sap (Jahan et al. 2014), while the leafminer larvae use their mouth hooks to feed in the mesophyll inside the leaves (Wei et al. 2000). The leafminer larvae and whitefly nymphs occur mainly on the basal and medium leaves of the melon's branch (Chagas et al. 2019). Therefore, both species coexist by feeding on the melon plants and their damage results in large economic losses in this agroecosystem (Baldin et al. 2012; Costa-Lima et al. 2019).

In tomatoes, B. tabaci infestation modifies the expression of proteins that may exert influence on other herbivores (Mayer et al. 2002). Field and laboratory studies showed that B. tabaci has a negative impact on the biological parameters of Liriomyza trifolii Burgess in tomatoes (Inbar et al. 1999). A similar result was obtained in cucumber and pumpkin plants infested with B. tabaci, in which the biological performance of L. sativae was low when compared to plants free from whiteflies (Zhang et al. 2005).

Melon crops in Brazilian semi-arid region becomes perfect models to test open field interactions, because whiteflies and leafminers are major pests of this crop, exploiting the same niche. Thus, the present research aimed to determine if there are positive or negative interactions between $L$. sativae and B. tabaci under field conditions.

\section{MATERIAL AND METHODS}

The study was conducted in Floresta, Pernambuco (PE), located in the semi-arid region of northeast Brazil. The city has a BSw'h' climate (very warm, semi-arid, steppe type), according to the Köppen classification, and 4aTh (warm tropical with severe drought) according to the Guassen classification (Jacomine et al. 1973).

Surveys were conducted in four commercial melon fields during two different periods. The first was from August to September of 2015 (A1 and A2) and the second was from March to May of 2016 (B1 and B2). The geographical coordinates of the studied areas were A1 ( $8^{\circ} 47^{\prime} 14,1^{\prime \prime} \mathrm{S}$ and $\left.38^{\circ} 34^{\prime} 54,7^{\prime \prime} \mathrm{W}\right), \mathrm{A} 2$ ( $8^{\circ} 36^{\prime} 49,9^{\prime \prime} \mathrm{S}$ and $\left.38^{\circ} 35^{\prime} 00,2^{\prime \prime} \mathrm{W}\right), \mathrm{B} 1{ }^{\circ} 38^{\prime} 16,5^{\prime \prime} \mathrm{S}$ and

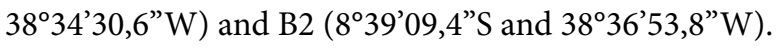

The studied fields ranged from 0.7 to 1.3 ha, all cultivated with yellow type melons. The crop was established with seeds, drip irrigation and without plastic mulching. In general, the fertilizer foundation was made with NPK (6-24-12). Other information about the crop management can be found in Table 1. In field A1, the phytosanitary measures were conducted until the fourth week. However, monitoring proceeded until the tenth week, when fruits were at harvest point.

The samplings were carried out weekly during the entire crop cycle. Eight to 10 samplings were done in each field, according to the harvest period. In each sampling, a total of 30 plants were randomly selected in each field and the tenth leaf (counted from the apex) was detached. The number of B. tabaci nymphs and L. sativae larvae were recorded. For the whiteflies, a $5 \mathrm{~cm}^{2}$ area was focused with a hand lens $(10 \times)$, in the leaf lower margin close to the midrib. Only fourth instar nymphs (red-eye presence) were registered. For $L$. sativae, live larvae (yellow colored) inside the mines in the entire leaf area were recorded. For the B. tabaci adults count, the melon apex branch (third leaf from the apex) was sampled on the leaf abaxial side.

Table 1. Melon crop management information about the four fields used in the experiments, Floresta (PE), Brazil.

\begin{tabular}{ccccc} 
Field & ha & Variety and spacing & Phytosanitary control & Nearby crops \\
\hline A1 & 1.3 & $\begin{array}{c}\text { Gladial, } \\
2.0 \times 0.3 \mathrm{~m}\end{array}$ & $\begin{array}{c}\text { Cartap + sugar and methomyl } \\
\text { 3 applications (weeks 1 to 3) }\end{array}$ & $\begin{array}{c}\text { Tomato (5.5 ha), watermelon (1.0 ha), onion } \\
(1.5 \mathrm{ha}) \text { and melon (9.5 ha). }\end{array}$ \\
\hline A2 & 1.2 & $\begin{array}{c}10 / 00, \\
2.2 \times 0.3 \mathrm{~m}\end{array}$ & $\begin{array}{c}\text { Methomyl + lambda-cyhalothrin (weekly } \\
\text { applications) }\end{array}$ & Melon (1.1 ha). \\
B1 & 1.0 & $\begin{array}{c}\text { Gladial, } \\
1.5 \times 0.3 \mathrm{~m}\end{array}$ & $\begin{array}{c}\text { Acetamiprid + acephate + cypermethrin + } \\
\text { abamectin. (weekly applications) }\end{array}$ & Tomato (5.0 ha) and melon (9.0 ha). \\
B2 & 0.7 & $\begin{array}{c}\text { Aladial, } \\
\text { (weekly applications) }\end{array}$ & Melon (1.0 ha)
\end{tabular}


The Shapiro-Wilk test was used to evaluate the normality of errors, with results suggesting the data does not follow a normal distribution. Therefore, generalized linear models (GLM) with a Poisson distribution of errors were used to analyze the influence of $L$. sativae larvae on B. tabaci nymphs or adults and vice-versa. This was done because the interest of this research was to explore the bidirectional relationship between the two insect species. For this reason, to investigate the negative, positive or neutral (not significant) coabundance, L. sativae and B. tabaci (nymphs or adults) were established both as dependent and independent variables. The statistical significance was evaluated with $\mathrm{p}<0.05$. The regression coefficient was used to estimate the positive or negative coabundance between species. Regression coefficients have been regularly used as a competition coefficient in several studies, emphasizing interspecific interaction and evidencing the competitive abilities of organisms (Hallett and Pimm 1979; Luo et al. 1998; Hart et al. 2018).

\section{RESULTS AND DISCUSSION}

Results show three relationship scenarios estimating coabundance patterns between L. sativae and B. tabaci (nymphs or adults) by using Poisson regression coefficients: neutral, positive and negative coabundance. The neutral pattern indicates no relationship between species (Tables 2 to 5), positive coabundance reveals an increasing trend between species (Fig. 1)

Table 2. Association between L. sativae (larvae) and B. tabaci (nymphs and adults) in melon field A1, June to August 2015, Floresta, Brazil.

\begin{tabular}{|c|c|c|}
\hline Week & Interaction & Coabundance effect \\
\hline \multirow{2}{*}{1} & L. sativae $\times$ B. tabaci (nymph) & ns \\
\hline & L. sativae $\times$ B. tabaci (adult) & $-0.14(p=5 e-02)$ \\
\hline \multirow{2}{*}{2} & L. sativae $\times$ B. tabaci (nymph) & ns \\
\hline & L. sativae $\times$ B. tabaci (adult) & ns \\
\hline \multirow{2}{*}{3} & $\begin{array}{l}\text { L. sativae } \times \text { B. tabaci }(\text { nymph }) \\
\text { L. sativae } \times \text { B. tabaci }(\text { nymph })\end{array}$ & $\begin{array}{l}0.67(p=1.29 e-12) \\
0.674(p=1.3 e-12)\end{array}$ \\
\hline & L. sativae $\times$ B. tabaci (adult) & ns \\
\hline \multirow[b]{2}{*}{4} & L. sativae $\times$ B. tabaci (nymph) & ns \\
\hline & $\begin{array}{l}\text { L. sativae } \times \text { B. tabaci (adult) } \\
\text { L. sativae } \times \text { B. tabaci (adult) }\end{array}$ & $\begin{array}{c}0.04(p=4.3 e-05) \\
0.01(p=1 e-02)\end{array}$ \\
\hline \multirow[t]{2}{*}{5} & $\begin{array}{l}\text { L. sativae } \times \text { B. tabaci }(\text { nymph }) \\
\text { L. sativae } \times \text { B. tabaci }(\text { nymph })\end{array}$ & $\begin{array}{l}0.09(p=2 e-16) \\
0.087(p=2 e-16)\end{array}$ \\
\hline & L. sativae $\times$ B. tabaci (adult) & ns \\
\hline \multirow{2}{*}{6} & L. sativae $\times$ B. tabaci (nymph) & ns \\
\hline & L. sativae $\times$ B. tabaci (adult) & ns \\
\hline \multirow{2}{*}{7} & $\begin{array}{l}\text { L. sativae } \times \text { B. tabaci }(\text { nymph }) \\
\text { L. sativae } \times \text { B. tabaci }(\text { nymph })\end{array}$ & $\begin{array}{c}0.057(p=2 e-16) \\
0.06(p=2 e-16)\end{array}$ \\
\hline & $\begin{array}{l}\text { L. sativae } \times \text { B. tabaci (adult) } \\
\text { L. sativae } \times \text { B. tabaci (adult) }\end{array}$ & $\begin{array}{l}-0.04(p=9 e-07) \\
-0.02(p=3 e-03)\end{array}$ \\
\hline \multirow[b]{2}{*}{8} & L. sativae $\times$ B. tabaci (nymph) & ns \\
\hline & $\begin{array}{l}\text { L. sativae } \times \text { B. tabaci (adult) } \\
\text { L. sativae } \times \text { B. tabaci (adult) }\end{array}$ & $\begin{array}{c}-0.03(p=6.6 e-05) \\
-0.01(p=1 e-02)\end{array}$ \\
\hline \multirow{2}{*}{9} & $\begin{array}{l}\text { L. sativae } \times \text { B. tabaci }(\text { nymph }) \\
\text { L. sativae } \times \text { B.tabaci }(\text { nymph })\end{array}$ & $\begin{array}{c}0.019(\mathrm{p} 2 \mathrm{e}-16) \\
0.02(\mathrm{p} 2 \mathrm{e}-16)\end{array}$ \\
\hline & $\begin{array}{l}\text { L. sativae } \times \text { B. tabaci (adult) } \\
\text { L. sativae } \times \text { B. tabaci (adult) }\end{array}$ & $\begin{array}{l}-0.009(p=5 e-03) \\
-0.02(p=2.34 e-05)\end{array}$ \\
\hline \multirow[t]{2}{*}{10} & $\begin{array}{l}\text { L. sativae } \times \text { B. tabaci }(\text { nymph }) \\
\text { L. sativae } \times \text { B. tabaci }(\text { nymph })\end{array}$ & $\begin{array}{l}0.025(p=1.12 e-05) \\
0.012(p=1.56 e-03)\end{array}$ \\
\hline & L. sativae $\times$ B. tabaci (adult) & ns \\
\hline
\end{tabular}

${ }^{*}$ Boldface $=$ species causing competitive effect. ns = not significant. 
Table 3. Association between L. sativae (larvae) and B. tabaci (nymphs and adults) in melon field A2, June to August 2015, Floresta, Brazil.

\begin{tabular}{|c|c|c|}
\hline Week & Interaction & Coabundance effect \\
\hline \multirow{2}{*}{1} & L. sativae $\times$ B. tabaci (nymph) & ns \\
\hline & L. sativae $\times$ B. tabaci (adult) & ns \\
\hline \multirow{2}{*}{2} & L. sativae $\times$ B. tabaci (nymph) & ns \\
\hline & L. sativae $\times$ B. tabaci (adult) & $-0.24(p=1.8 e-02)$ \\
\hline \multirow{2}{*}{3} & L. sativae $\times$ B. tabaci (nymph) & ns \\
\hline & L. sativae $\times$ B. tabaci (adult) & ns \\
\hline \multirow{2}{*}{4} & L. sativae $\times$ B. tabaci (nymph) & ns \\
\hline & L. sativae $\times$ B. tabaci (adult) & ns \\
\hline \multirow{2}{*}{5} & L. sativae $\times$ B. tabaci (nymph) & ns \\
\hline & L. sativae $\times$ B. tabaci (adult) & ns \\
\hline \multirow{2}{*}{6} & L. sativae $\times$ B. tabaci (nymph) & ns \\
\hline & L. sativae $\times$ B. tabaci (adult) & ns \\
\hline \multirow[t]{2}{*}{7} & $\begin{array}{l}\text { L. sativae } \times \text { B. tabaci }(\text { nymph }) \\
\text { L. sativae } \times \text { B. tabaci }(\text { nymph })\end{array}$ & $\begin{array}{l}-0.10(p=5.52 e-08) \\
-0.014(p=5 e-02)\end{array}$ \\
\hline & L. sativae $\times$ B. tabaci (adult) & ns \\
\hline \multirow{2}{*}{8} & L. sativae $\times$ B. tabaci (nymph) & $0.04(p=4 e-03)$ \\
\hline & L. sativae $\times$ B. tabaci (adult) & ns \\
\hline 9 & $\begin{array}{l}\text { L. sativae } \times \text { B. tabaci (adult) } \\
\text { L. sativae } \times \text { B. tabaci (adult) }\end{array}$ & $\begin{array}{c}-0.09(p=4.56 e-05) \\
-0.03(p=2 e-02)\end{array}$ \\
\hline
\end{tabular}

${ }^{*}$ Boldface $=$ species causing competitive effect. $\mathrm{ns}=$ not significant.

Table 4. Association between L. sativae (larvae) and B. tabaci (nymphs and adults) in melon field B1, March to May 2016, Floresta, Brazil.

\begin{tabular}{|c|c|c|}
\hline Week & Interaction & Coabundance effect \\
\hline \multirow{2}{*}{1} & L. sativae $\times$ B. tabaci (nymph) & ns \\
\hline & L. sativae $\times$ B. tabaci (adult) & ns \\
\hline \multirow[b]{2}{*}{2} & L. sativae $\times$ B. tabaci (nymph) & $-0.34(p=5.9 e-07)$ \\
\hline & $\begin{array}{l}\text { L. sativae } \times \text { B. tabaci (adult) } \\
\text { L. sativae } \times \text { B. tabaci (adult) }\end{array}$ & $\begin{array}{c}0.20(p=2.8 e-09) \\
0.04(p=4 e-03)\end{array}$ \\
\hline \multirow{2}{*}{3} & L. sativae $\times$ B. tabaci (nymph) & ns \\
\hline & L. sativae $\times$ B. tabaci (adult) & ns \\
\hline \multirow{2}{*}{4} & L. sativae $\times$ B. tabaci (nymph) & ns \\
\hline & L. sativae $\times$ B. tabaci (adult) & ns \\
\hline \multirow{2}{*}{5} & L. sativae $\times$ B. tabaci (nymph) & ns \\
\hline & L. sativae $\times$ B. tabaci (adult) & ns \\
\hline \multirow{2}{*}{6} & L. sativae $\times$ B. tabaci (nymph) & ns \\
\hline & L. sativae $\times$ B. tabaci (adult) & ns \\
\hline \multirow{2}{*}{7} & L. sativae $\times$ B. tabaci (nymph) & ns \\
\hline & L. sativae $\times$ B. tabaci (adult) & ns \\
\hline \multirow[b]{2}{*}{8} & L. sativae $\times$ B. tabaci (nymph) & ns \\
\hline & $\begin{array}{l}\text { L. sativae } \times \text { B. tabaci (adult) } \\
\text { L. sativae } \times \text { B. } \text { tabaci (adult) }\end{array}$ & $\begin{array}{c}-0.14(p=1.41 e-06) \\
-0.03(p=3 e-02)\end{array}$ \\
\hline
\end{tabular}

*Boldface $=$ species causing competitive effect. $\mathrm{ns}=$ not significant. 
Table 5. Association between Liriomyza sativae (larvae) and Bemisia tabaci (nymphs and adults) in melon field B1, March to May 2016, Floresta, Brazil.

\begin{tabular}{|c|c|c|}
\hline Week & Interaction & Coabundance effect \\
\hline \multirow{2}{*}{1} & L. sativae $\times$ B. tabaci (nymph) & ns \\
\hline & L. sativae $\times$ B. tabaci (adult) & ns \\
\hline \multirow{2}{*}{2} & L. sativae $\times$ B. tabaci (nymph) & ns \\
\hline & L. sativae $\times$ B. tabaci (adult) & ns \\
\hline \multirow{2}{*}{3} & L. sativae $\times$ B. tabaci (nymph) & ns \\
\hline & L. sativae $\times$ B. tabaci (adult) & ns \\
\hline \multirow{2}{*}{4} & L. sativae $\times$ B. tabaci (nymph) & ns \\
\hline & L. sativae $\times$ B. tabaci (adult) & $-0.08(p=0.05)$ \\
\hline \multirow[b]{2}{*}{5} & L. sativae $\times$ B. tabaci (nymph) & ns \\
\hline & $\begin{array}{l}\text { L. sativae } \times \text { B. tabaci (adult) } \\
\text { L. sativae } \times \text { B. tabaci (adult) }\end{array}$ & $\begin{array}{c}-0.18(p=3.43 e-05) \\
-0.07(p=2 e-02)\end{array}$ \\
\hline \multirow{2}{*}{6} & L. sativae $\times$ B. tabaci (nymph) & $-0.10(p=1 e-03)$ \\
\hline & L. sativae $\times$ B. tabaci (adult) & ns \\
\hline \multirow{2}{*}{7} & L. sativae $\times$ B. tabaci (nymph) & ns \\
\hline & L. sativae $\times$ B. tabaci (adult) & ns \\
\hline \multirow{2}{*}{8} & L. sativae $\times$ B. tabaci (nymph) & ns \\
\hline & L. sativae $\times$ B. tabaci (adult) & ns \\
\hline \multirow{2}{*}{9} & L. sativae $\times$ B. tabaci (nymph) & ns \\
\hline & L. sativae $\times$ B. tabaci (adult) & ns \\
\hline
\end{tabular}

*Boldface $=$ species causing competitive effect. ns = not significant.

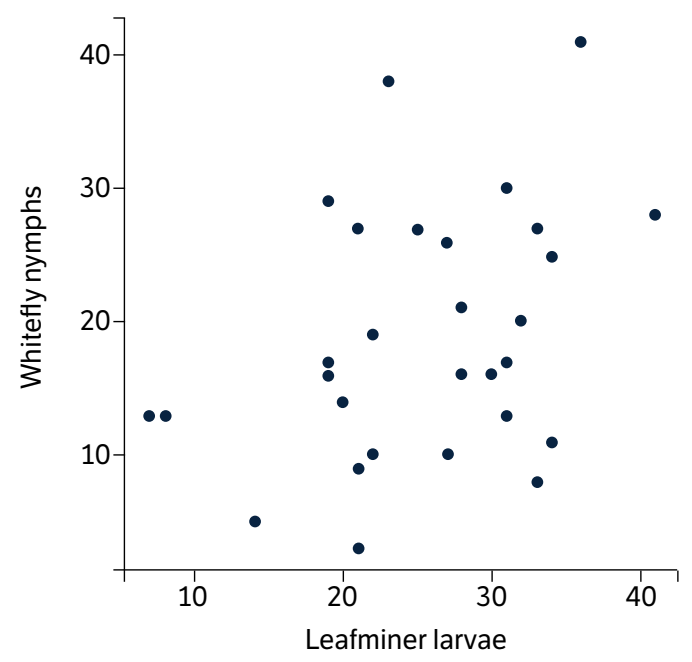

Figure 1. Influence of $L$. sativae larvae on B. tabaci nymphs indicating positive coabundance from collections obtained in melon field A1, August 27, 2015.

and the negative shows a decreasing trend between species (Fig. 2). In the current study, it was chosen to present just two figures to illustrate these relationships between species, since the graphs represent the several other analyzed interactions very well. Tables 2 to 5 show the significance of the coabundance between the two species, as well as the coabundance effect given by the Poisson regression coefficient in four different fields described in Table 1. 
In field A1 with among 29 interactions, 10 exhibited an absence of significance between dependent and independent variables (Table 2). Twelve interactions exhibited a positive coabundance between L. sativae and B. tabaci, with 10 showing leafminers versus whitefly nymphs and two for $L$. sativae and B. tabaci adults (Table 2). Seven interactions showed a negative coabundance in field A1 and, among them, just one exhibited unidirectional negative impact on the other competitor (Table 2).

Among 19 interactions were observed in field A2, 13 of them exhibited not significant coabundance, one showed a positive interaction between $L$. sativae and nymphs and five indicated negative interactions, with three involving adults of $B$. tabaci and two showing interactions with nymphs (Table 3). Only one negative coabundance took place in a unidirectional way (Table 3).

In field B1 there were among 18 interactions, 13 were not significant, two positives and three negatives (Table 4). The positive ones occurred between L. sativae and B. tabaci adults. For the negatives, two involved whiteflies adults and one for the nymphs (Table 4) and one of them exhibited a unidirectional interaction (Table 4). In B2 there were among 19 interactions, 15 were not significant, four exhibited a negative coabundance and none were positive (Table 5). Among the negative interactions, just one was observed involving nymphs of $B$. tabaci, while the other three involved interactions between L. sativae and B. tabaci adults (Table 5).

The results suggest the occurrence of negative, positive and neutral coabundance between the two species. The negative coabundance indicates the occurrence of interspecific competition, while the positive relationships suggest no competition. Among 85 interactions were investigated, 19 were negative, 15 were positive and 51 were not significant or neutral. Among the 34 significant interactions, 56\% were negative, suggesting that more than half of the significant interactions are due to interspecific competition. The results obtained indicate that competition can occur between L. sativae and B. tabaci in melon crops in the studied conditions. Based on the Poisson regressions, only $22 \%$ of the interactions suggest the occurrence of competition with negative effect, $18 \%$ indicates the existence of positive interactions and $60 \%$ are neutral interactions. Negative coabundance comes from the ability of a species to negatively impact its competitor by consuming the shared resources in an uneven way and, in this study, it is represented by the significant negative regression slope value (Crowell and Pimm 1976; Hallett and Pimm 1979; Luo et al. 1998). Positive coabundance comes from the ability of two species to use shared resources without causing a negative impact into each other and, in this study, it was indicated by a positive slope value. In neutral coabundance, species are totally independent of each other and is currently determined by the absence of significance between the species abundances.

Although the two species have distinct feeding behavior, both share the same host plant, coexisting in time and space, increasing the likelihood of competition (Schoener 1974; Connell 1980). Among the 19 negative effects, 11 were caused by L. sativae and eight by B. tabaci. Although results indicate a slight advantage for L. sativae, the difference between the number of negative effects among the two species is not high. In tomatoes, a reduction in L. trifolii oviposition, feeding puncture and

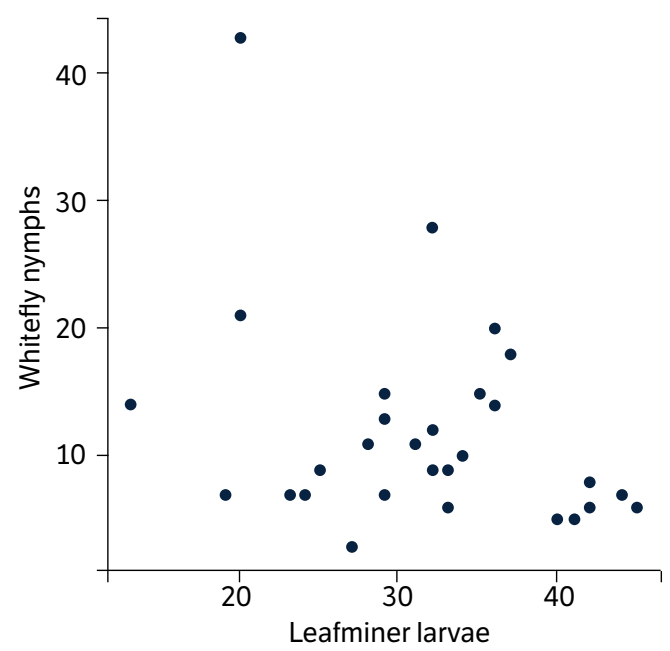

Figure 2. Influence of L. sativae larvae on B. tabaci adults indicating negative coabundance from collections obtained in melon field A1, August 13, 2015. 
larval viability was observed in plants previously infested with $B$. tabaci, whereas this effect did not occur in the reverse order (Inbar et al. 1999). Negative effects on L. sativae were also observed in pumpkin and cucumber previously infested with B. tabaci, which reduced the number of mines number and the weight of fly pupae (Zhang et al. 2005). Defense mechanisms of plants, triggered by the insects feeding, may be involved in these cases. It has been observed that tomato plants infested with $B$. tabaci and $L$. trifolii produce proteins related to the pathogenesis (PR-proteins), some restricted to the feeding site, others in a systemic way (Inbar and Gerling 2008). These proteins, such as chitinases, $\beta$-1,3-glucanase and peroxidases, may express insecticidal and antimicrobial activity (Mayer et al. 2002). However, these proteins or secondary plant metabolites are usually not found in the phloem, making chewing insects more susceptible to these compounds compared to sucking insects (Zhang et al. 2005). Also, the whiteflies secrete a viscous saliva that forms a sheath that lubricates the stylet pathway and protects against these compounds when penetrating the plant (Mayer et al. 2002). Thus, B. tabaci can induce plant defenses without being affected, overcoming other herbivores in competition (Mayer et al. 1996, 2002). Considering the PR-proteins expression, these are generally more intense at the site where the injury occurred immediately after feeding (Karban and Baldwin 1997). In melon plants, L. sativae larvae and B. tabaci more developed nymphs occur predominantly in the branch middle region (Chagas et al. 2019). Therefore, the whitefly may trigger more intense plant defense responses at the feeding site and possibly interferes in the leafminers' development. On the other hand, a recent study identified a protein (Bt56) inserted by B. tabaci in tobacco plants that elicits the salicylic acid signaling pathway and, consequently, suppresses the effective jasmonic acid defenses (Xu et al. 2019).

The current results clearly show a higher number of interactions taking place in A1 than other fields, in addition to a lower number of non-significant interactions. Field A1 had phytosanitary measures applied only during the first four weeks, while the other melon fields had a weekly use of insecticides. Thus, a higher number of each pest was observed, mainly L. sativae. Consequently, the probability of finding B. tabaci also increased.

\section{CONCLUSION}

Most interactions between L. sativae and B. tabaci in melon crops in the Brazilian semi-arid region are neutral. Among the significant interactions most are negative, suggesting that these interactions are due to interspecific competition with negative coabundance.

\section{AUTHORS' CONTRIBUTION}

Conceptualization: Costa-Lima, T. C. and Lemos L. J. U.; Methodology: Godoy, W. A. C., Costa-Lima, T. C. and Lemos L. J. U.; Investigation: Lemos L. J. U. and Barros, R. V.; Writing - Original Draft: Lemos L. J. U., Costa-Lima, T. C., Barros, R. and Godoy, W. A. C.; Writing - Review and Editing: Costa-Lima, T. C. and Godoy, W. A. C.; Funding Acquisition: CostaLima, T. C.; Resources: Barros, R.; Supervision: Barros, R. and Costa-Lima, T. C.

\section{DATA AVAILABILITY STATEMENT}

All dataset were generated or analyzed in the current study.

\section{ACKNOWLEDGEMENTS}

To Túlio Silva for the aid in the field work and to the melon producers of Floresta for allowing to use their areas in the experiments. 


\section{FUNDING}

Coordenação de Aperfeiçoamento de Pessoal de Nível Superior

[http://doi.org/10.13039/501100002322]

Empresa Brasileira de Pesquisa Agropecuária

[http://doi.org/10.13039/501100003046]

Project number 02.14.16.002.00.00

\section{REFERENCES}

Baldin, E. L. L., Silva, J. P. G. F. and Pannuti, L. E. R. (2012). Resistance of melon cultivars to Bemisia tabaci biotype B. Horticultura Brasileira, 30, 600-606. https://doi.org/10.1590/S0102-05362012000400007

Begon, M., Townseed, C. R. and Harper, J. L. (2005). Ecology: From Individuals to Ecosystems. Oxford: Wiley-Blackwell.

Brodie, J. F., Helmy, O. E., Mohd-Azlan, J., Granados, A., Bernard, H., Giordano, A. J. and Zipkin, E. (2018). Models for assessing local-scale co-abundance of animal species while accounting for differential detectability and varied responses to the environment. Biotropica, 50, 5-15. https://doi.org/10.1111/btp.12500

Chagas, M. C. M., Costa-Lima, T. C. and Silva, J. R. (2019). Manejo de pragas. In C. Nick and A. Borém (Eds.), Melão do plantio à colheita (p. 118-146). Viçosa: UFV.

Chesson, P. (2000). Mechanisms of Maintenance of Species Diversity. Annual Review of Ecology and Systematics, 31, 343-366. https:// doi.org/10.1146/annurev.ecolsys.31.1.343

Connell, J. H. (1980). Diversity and the coevolution of competitors, or the ghost of competition past. Oikos, 35, 131-138. https://doi. $\operatorname{org} / 10.2307 / 3544421$

Costa-Lima, T. C., Chagas, M. C. M. and Parra, J. R. P. (2019). Comparing Potential as Biocontrol Agents of Two Neotropical Parasitoids of Liriomyza sativae. Neotropical Entomology, 48, 660-667. https://doi.org/10.1007/s13744-018-00667-0

Crowell, K. L. and Pimm, S. L. (1976). Competition and niche shifts of mice introduced onto small islands. Oikos, 27, 251-258. https://doi. $\operatorname{org} / 10.2307 / 3543903$

Di Bitetti, M. S., Di Blanco, Y. E., Pereira, J. A., Paviolo, A. and Pírez, I. J. (2009). Time partitioning favors the coexistence of sympatric crab-eating foxes (Cerdocyon thous) and Pampas foxes (Lycalopex gymnocercus). Journal of Mammalogy, 90, 479-490. https://doi. org/10.1644/08-MAMM-A-113.1

Gotelli, N. J. (2000). Null model analysis of species co-occurrence patterns. Ecology, 81, 2606-2621. https://doi. org/10.1890/0012-9658(2000)081[2606:NMAOSC]2.0.CO;2

Hallet, J. G. and Pimm, S. L. (1979). Direct estimation of competition. The American Naturalist, 113, 593-600. https://doi.org/10.1086/283415 Hart, S. P., Freckleton, R. P. and Levine, J. M. (2018). How to quantify competitive ability. Journal of Ecology, 106, 1902-1909. https://doi. org/10.1111/1365-2745.12954

Inbar, M., Doostdar, H., Leibee, G. L. and Mayer, R. T. (1999). The role of plant rapidly induced responses in asymmetric interspecific interactions among insect herbivores. Journal of Chemical Ecology, 25, 1961-1979. https://doi.org/10.1023/A:1020998219928 
Inbar, M. and Gerling, D. (2008). Plant-mediated interactions between whiteflies, herbivores and natural enemies. Annual Review of Entomology, 53, 431-448. https://doi.org/10.1146/annurev.ento.53.032107.122456

Jacomine, P. K. T., Cavalcanti, A. C., Burgos, N. and Pessoa, S. C. P. (1973). Levantamento exploratório: reconhecimento de solos do estado de Pernambuco. Recife: DNPEA.

Jahan, S. M. H., Lee, G.-S., Lee, S. and Lee, K.-Y. (2014). Upregulation of probing and feeding related behavioural frequencies in Bemisia tabaci upon acquisition of Tomato yellow leaf curl virus. Pest Management Science, 70, 1497-1502. https://doi.org/10.1002/ps.3828

Kaplan, I., Sardanelli, S., Rehill, B. J. and Denno, R. F. (2011). Toward a mechanistic understanding of competition in vascular-feeding herbivores: an empirical test of the sink competition hypothesis. Oecologia, 166, 627-636. https://doi.org/10.1007/s00442-010-1885-9

Karban, R. and Baldwin, I. T. (1997) Induced responses to herbivory. Chicago: University of Chicago Press. https://doi.org/10.7208/ chicago/9780226424972.001.0001

Luo, J., Monamy, V. and Fox, B. J. (1998). Competition between two Australian rodent species: a regression analysis. Journal of Mammalogy, 79, 962-971. https://doi.org/10.2307/1383104

Mayer, R. T., McCollum, T. G., McDonald, R. E., Polston, J. E. and Doostdar, H. (1996). Bemisia feeding induces pathogenesis-related proteins in tomato. In D. Gerling and R. T. Mayer (Eds.), Bemisia 1995: Taxonomy, Biology, Damage, Control and Management (p. 179188). Andover: Intercept Ltd.

Mayer, R. T., Inbar, M., McKenzie, C. L., Shatters, R., Borowicz, V., Albrecht, U., Powell, C. A. and Doostdar, H. (2002). Multitrophic interactions of the silverleaf whitefly, host plants, competing herbivores and phytopathogens. Archives of Insect Biochemistry and Physiology, 51, 151-169. https://doi.org/10.1002/arch.10065

Schoener, T. W. (1974). Resource partitioning in ecological communities. Science, 185, 27-39. https://doi.org/10.1126/science.185.4145.27 Wei, J., Zou, L., Kuang, R. and He, L. (2000). Influence of leaf tissue structure on host feeding selection by pea leafminer Liriomyza huidobrensis (Diptera: Agromyzidae). Zoological Studies, 39, 295-300.

Xu, H.-X., Qian, L.-X., Wang, X.-W., Shao, R.-X., Hong, Y., Liu, S.-S. and Wang, X.-W. (2019). A salivary effector enables whitefly to feed on host plants by eliciting salicylic acid-signaling pathway. Proceedings of the National Academy of Sciences of United States of America, 116, 490-495. https://doi.org/10.1073/pnas.1714990116

Zhang, L.-P., Zhang, G.-Y., Zhang, Y.-J., Zhang, W.-J. and Liu, Z. (2005). Interspecific interactions between Bemisia tabaci (Hem., Aleyrodidae) and Liriomyza sativae (Dipt., Agromyzidae). Journal of Applied Entomology, 129, 443-446. https://doi.org/10.1111/j.1439-0418.2005.00991.x 